\title{
PREDICTING CAREER DECISION-MAKING STRATEGIES IN WOMEN: THE ROLE OF SELF-DETERMINATION AND PERCEIVED EMOTIONAL INTELLIGENCE
}

\author{
Veronika LÁTALOVÁ, L’ubor PILÁRIK \\ Department of Psychological Sciences, Faculty of Social Sciences and Health Care \\ Constantine the Philosopher University in Nitra \\ Kraskova 1, 94974 Nitra, Slovak Republic \\ E-mail: veronika.latalova@ukf.sk, lpilarik@ukf.sk
}

\begin{abstract}
The aim of the present research was to investigate the role of self-determination (SD) and perceived emotional intelligence (EI) in adopting specific career decision-making strategies (CDMSs), and thereby to extend knowledge about personality factors playing a crucial role in adaptive ways of making career decisions. The study was conducted on a sample of 173 first-year university female students aged 19-25 using the questionnaires Career Decision-Making Profile (CDMP; Gati et al., 2010), Career Decision-Making Autonomy Scale (CDMAS; Guay, 2005), Academic Motivation Scale-College (AMS-C; Vallerand et al., 1992), and Trait Meta-Mood Scale (TMMS; Salovey et al., 1995). The results supported the importance of SD and perceived EI in predicting adaptive career decision-making (CDM); SD accounted for 2-34\% of variance in CDMSs and the perceived EI explained additional up to $11 \%$ of their variance, even after controlling for SD. Higher SD and perceived EI were associated with more frequent use of adaptive and less frequent use of maladaptive CDMSs. Our findings might be relevant to career counselling.
\end{abstract}

Key words: career decision-making strategies, self-determination, autonomous regulation, perceived emotional intelligence

The aim of the present research was to investigate the role of self-determination (SD) and perceived emotional intelligence (EI) in adopting specific career decision-making strategies (CDMSs), and thereby to extend knowledge about personality factors playing a crucial role in adaptive career decisionmaking (CDM).

\section{Adaptiveness of Career Decision-Making}

Adaptive CDM, along with career planning and career exploration, is seen as an essen-

Acknowledgement

This research was supported by the grant VEGA No.1/0446/14 tial component of coping with career development. To date, several models have been introduced defining basic criteria for assessing adaptiveness of decision-making. The issue of decision-making adaptiveness has been approached from either normative or descriptive perspective (Gati, Landman, Davidovitch, Asulin-Peretz, \& Gadassi, 2010; Phillips, 1997).

Normative models are derived from economic and probabilistic conceptions of decision-making processes with the Subjective Expected Utility (SEU) model being the standard. They are aimed at postulating such decision-making procedures which should lead to optimal choice. People are considered fully rational decision-makers, when

DOI: $10.21909 /$ sp.2015.02.686 
they are able to obtain and process all information necessary to assess each alternative (Baláž, 2010; Gati \& Tal, 2008; Phillips, 1997).

Descriptive models rely on the proposition that not only rational decision-making procedures meet the criteria for adaptive coping with career development. Their aim is to redefine adaptiveness of CDM in terms of "other than rational" decision-making strategies. Modern descriptive CDM models pursue a process approach to assessing decision-making adaptiveness. Instead of evaluating decision outcomes - that is, achieving distinct goals - descriptive models address the question of the manner of making decisions - that is, what decision-making strategies provide conditions to eliminate inhibiting factors of CDM and support the facilitating ones. These factors are supposed to be preconditions for achieving pursued goals and thereby contribute to maintenance and enhancement of one's subjective well-being (Gati et al., 2010; Látalová \& Pilárik, in press; Phillips, 1997).

\section{Adaptiveness of Specific Career Decision- Making Strategies}

Gati et al. (2010) have recently introduced a multidimensional descriptive model involving 12 basic dimensions or strategies of CDM. In order to measure the level of each dimension in individuals' CDM processes and thereby build up detailed profile of strategies they adopt to make career choices, the authors constructed an instrument Career Decision-Making Profile (CDMP). This enabled them to empirically investigate, which pole of each CDMP dimension is more adaptive according to some alternative, otherthan-rational criteria characterizing CDM process (specifically emotional and personality- related CDM difficulties, five factors of the Big Five personality model, decision status describing individuals as decided, partially decided, or undecided, and CDM self-efficacy).

Using these criteria for assessing adaptiveness of CDMP dimensions, they arrived at the conclusion that comprehensive information gathering, analytic information processing, internal locus of control, much effort invested, less procrastination, greater speed of making final decision, less dependence on others, less desire to please others, higher aspiration for an ideal occupation, and less willingness to compromise proved to be more adaptive than the opposite ways of making career decisions. Only the level of consulting with others did not matter with regard to the above mentioned criteria (Gadassi, Gati, \& Dayan, 2012; Gadassi, Gati, \& Wagman-Rolnick, 2013). Moreover, in our previous research, based on the assumption that within CDM framework, core measures of subjective well-being are decision-making satisfaction and decision-making regret (DeHaan, Weinstein, \& Deci, 2013), we found that CDMSs that were proved to be adaptive or maladaptive in studies by Gadassi et al. (2012,2013), were equally adaptive or maladaptive, according to these two other-than-rational emotion-related criteria (Látalová \& Pilárik, in press).

As to the preference for particular CDMSs, Gati et al. (2010) suggest that it is conditioned by both, situational and personality factors.

\section{Personality Factors of Specific Career Decision-Making Strategies}

Although there are some previous studies and explanations investigating and discussing the relationship between specific deci- 
sion-making styles and personality traits such as EI directly without a third variable (e.g., Avsec, 2012; Di Fabio \& Blustein, 2010; Di Fabio \& Kenny, 2012; Laborde, Dosseville, \& Scelles, 2010; Pilárik \& Sarmány-Schuller, 2009), our own research program aims at offering a somewhat novel viewpoint in this field of study. Our predictions about personality dispositions associated with adoption of adaptive CDMSs follow from recent conceptions of personality integration.

Personality integration, found to be an essential source of psychological functioning (Jurišová \& Sarmány-Schuller, 2013), is also reflected in adaptiveness of CDM. Integrated individuals are aware of their current experiential contents and core aspects of self, are emotionally non-defensive and their decisions are experienced as self-determined, that is, autonomously regulated. According to modern conceptions of personality integration, the most important dispositional sources of personality integration have been designated SD and perceived EI (Weinstein, Przybylski, \& Ryan, 2013).

Numerous research findings presented by Deci and Ryan (2008) indicate that integrated persons are aware of their motives as well as emotions and adopt decision-making strategies congruent with their personal values and life goals (Sheldon \& Kasser, 1995). It is therefore highly probable that high levels of SD and perceived EI, being central dispositional factors of personality integration, would lead one to adopt adaptive (nondefensive) CDMSs.

Self-Determination and Career DecisionMaking Strategies

SD is conceptualized as a subjective belief that one initiates and regulates his/her be- haviors, decisions and goals. According to the self-determination theory (SDT), there are two basic types of motivation - intrinsic and extrinsic, differing in the extent of SD. They are conceived as opposite poles of continuum, reflecting various levels of autonomous regulation. SDT specifies three forms of extrinsic motivation distinguished by their level of autonomy and sources (Deci \& Ryan, 1985, 2008) (see Table 1).

Based on modern conceptions of personality integration (Weinstein et al., 2013), it might be expected that because the two necessary preconditions for autonomous regulation to take place are self-awareness and nondefensive approach to experiences and elements of self, preference for adaptive decision-making strategies is also supported by perceived EI, even beyond the effect of SD.

\section{Perceived Emotional Intelligence and Career Decision-Making Strategies}

To date, there have been formulated various conceptions and models of EI (e.g., Baron, 2006; Goleman, 1997; Petrides \& Furnham, 2000, 2001).

Trait EI and ability EI ${ }^{1}$ are two constructs of EI, distinguished by a measurement

\footnotetext{
${ }^{1}$ The distinction between trait EI and ability EI (Petrides \& Furnham, 2000, 2001) is unrelated to Mayer et al.'s (2000) distinction between "ability" and "mixed" models of EI. Petrides and Furnham's differentiation is based on the method of measurement (self-report versus maximumperformance) and views the resultant constructs as qualitatively different. In contrast, Mayer et al. attempt to differentiate on the basis of whether a model "mixes" cognitive abilities with other characteristics. If it does, it is a "mixed" model, and if it does not, it is an "ability" model.
} 
Table 1 Specification of motivation types and regulation forms

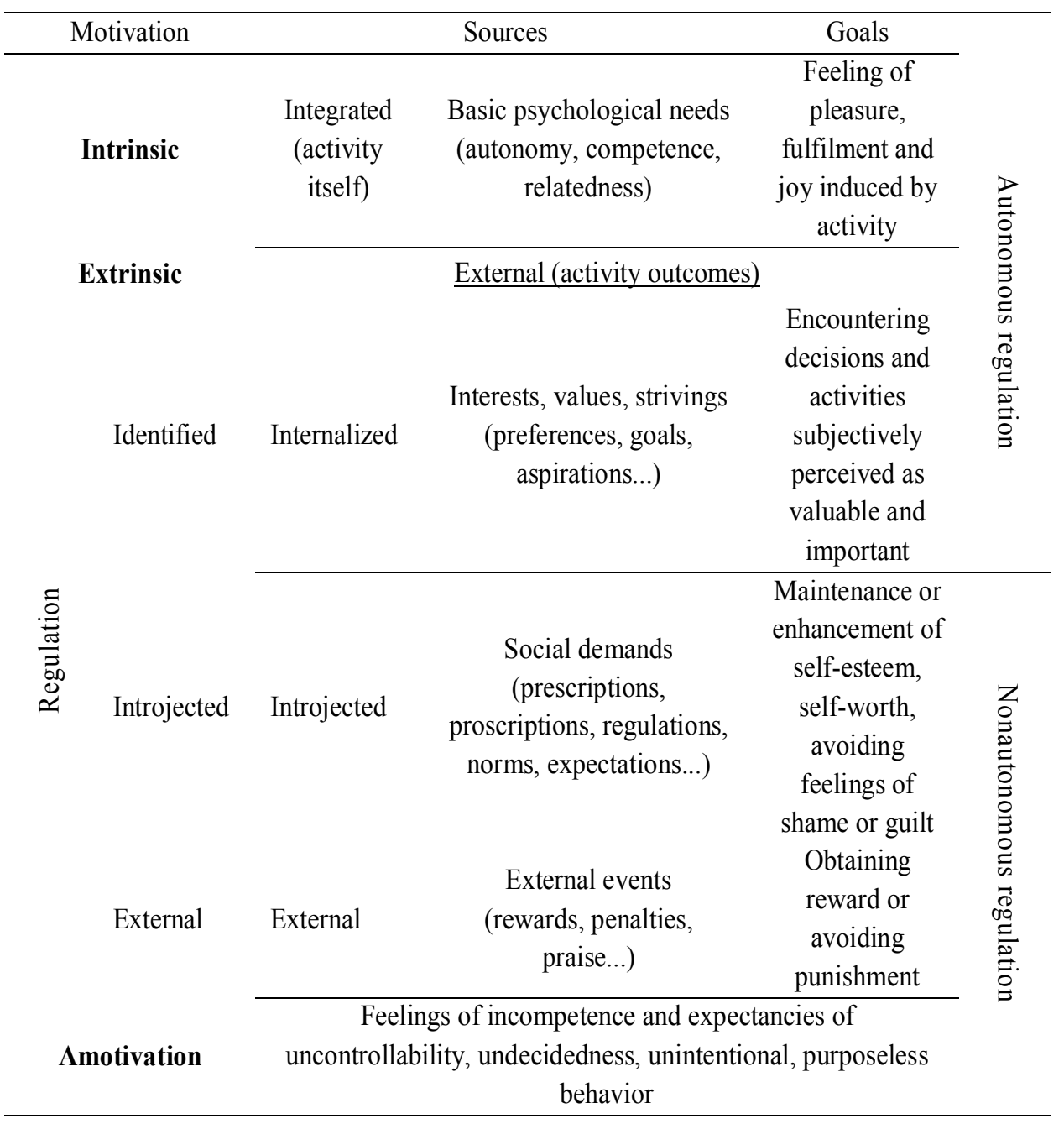

method used in the operationalization process (Petrides \& Furnham, 2000, 2001). Trait EI (or "trait emotional self-efficacy"), also referred to as "self-reported", "perceived" or "characteristic" EI, concerns emotion-related dispositions and self-perceptions, measured via self-report inventories assessing typical behavior, as in personality questionnaires. Trait EI is embedded within personality framework, whereby, this approach to EI research draws heavily on personality variables rather than essential elements of 
EI. Ability EI (or "cognitive-emotional ability") formerly referred to as information-processing EI (Petrides \& Furnham, 2000) concerns emotion-related cognitive abilities that can be best assessed through maximum-performance measures, as in IQ tests. This approach is much more focused and explicit as to the constituent parts of EI and its relationship to traditional intelligence. Conceptual differences between both constructs are directly reflected in empirical findings, which reveal very low, often nonsignificant, correlations between measures of trait EI and ability EI (Petrides \& Furnham, 2000, 2001).

Salovey and Mayer (1990) were the first who presented the idea about differentiation between the two aspects of EI. Firstly, they introduced a model of ability AI, defined as a set of competencies enabling one to identify, regulate and utilize his/her and other's feelings in self-motivation, adaptive behavior and decision-making (Mayer \& Salovey, 1997). Secondly, they proposed a conception of meta-mood experience conceptualized as a set of self-perceptions and subjective beliefs about one's EI competencies (Salovey, Mayer, Goldman, Turvey, \& Palfai, 1995; Salovey, Stroud, Woolery, \& Epel, 2002). Meta-experience of emotions is a necessary prerequisite for understanding information conveyed by emotions, identification of their actual sources and their adaptive regulation. It reflects "what we do about emotions" rather than "how emotions are experienced" (Seo \& Barrett, 2007).

Salovey et al. (1995) identified three elementary dimensions of meta-mood experience, found to be relatively stable personality traits - Attention to feelings, Clarity of feelings and Mood repair. They are not conceptualized as abilities in the traditional sense but rather as noncognitive self-reflective components of "perceived EI" (Salovey et al., 2002). Conception of meta-mood experience is thus ranked among the theories of trait EI (Petrides \& Furnham, 2000, 2001).

The important role of perceived EI in the preference for adaptive decision-making strategies is addressed by the Affect-as-information approach (Gohm \& Clore, 2002; Schwarz, 2012). The core idea is that emotions serve as important source of information, which people utilize in making everyday judgments and decisions when responding to the question "How do I feel about it?". As a consequence, emotions serve not only informational but also motivational function. The extent, to which people notice affective clues, take them into account when making judgments and decisions, and allow them to motivate their behavior, is regarded as a precondition for developing EI (Mayer \& Salovey, 1997).

Assumptions about perceived EI, as an important SD correlate and personality disposition facilitating preference for adaptive CDMSs, are supported by numerous research findings (e.g., Pilárik \& SarmánySchuller, 2009). In several studies presented by Fernández-Berrocal and Extremera (2008), it was found that with regard to intrinsic motivation for study and achieving satisfactory school grades, students' perceived EI is at least as important as their cognitive abilities and personality dispositions, as it facilitates their coping abilities. In a set of studies on factors facilitating career success, it was shown that perceived EI was positively related to adaptive CDMSs and negatively associated with various CDM difficulties (Di Fabio \& Palazzeschi, 2009; Di Fabio, Palazzeschi, \& Bar-On, 2012), including career undecidedness (Di Fabio, 
Palazzeschi, Asulin-Peretz, \& Gati, 2013; Di Fabio \& Saklofske, 2014). In a similar research it was found that deficits in the intrapersonal component of perceived EI contributed substantially to preference for maladaptive (e.g., avoidant and dependant) decision-making styles, over and above other personality traits of the decision-maker (Di Fabio \& Blustein, 2010; Di Fabio \& Kenny, 2012).

\section{The Present Research}

Based on the above presented conceptions and findings, we expected that SD (autonomous regulation) as well as perceived EI should be important intercorrelated predictors of specific CDMSs and that perceived EI should predict CDMSs even after controlling for the effect of SD, which was found to be an important personality correlate as well as predictor of adaptive CDM in previous studies (e.g., Guay, 2005; Guay, Senécal, Gauthier, \& Fernet, 2003; Látalová \& Pilárik, 2013). More specifically, we hypothesized that:

H1: There would be positive relationships between three qualities of perceived EI (i.e., attention to feelings, clarity of feelings and mood repair) and autonomous forms of regulation (i.e., intrinsic motivation and identified regulation), and negative relationships between three qualities of perceived EI and nonautonomous forms of regulation (i.e., introjected regulation, external regulation and amotivation).

$\mathrm{H} 2$ : Autonomous forms of regulation would be positive predictors of adaptive CDMSs (i.e., comprehensive information gathering, analytic information processing, effort invested, internal locus of control, speed of making a final decision, aspiration for ideal occupation and using intuition) and negative predictors of maladaptive CDMSs (i.e., procrastination, dependence on others, desire to please others and willingness to compromise).

H3: Nonautonomous forms of regulation would be negative predictors of adaptive CDMSs and positive predictors of maladaptive CDMSs.

H4: Three qualities of perceived EI would be positive predictors of adaptive CDMSs and negative predictors of maladaptive CDMSs, even after controlling for the SD effect.

As for the strategy of consultation with others, we formulated no specific predictions, since findings about its adaptiveness have been ambiguous (Gadassi et al., 2012; Látalová \& Pilárik, in press).

\section{Methods}

\section{Participants}

A total of 173 Slovak first-year female undergraduates aged 19-25 $(M=19.72, S D=$ 1.178 ) voluntarily participated in study. The sample was composed of students enrolled in social sciences disciplines. Main criterion for the selection of the participants was their recent experience in making a career decision about university study.

As present research is only the first of a series of studies that we aim to conduct in order to elaborately investigate the relationships between SD, perceived EI and CDMSs, at this point we decided to include only women in our sample. In our further research efforts, we intend to replicate the investigation in this field of study in male samples as well, which will enable us to identify potential gender differences. 


\section{Materials}

Participants were administered the following questionnaires ${ }^{2}$ :

Career Decision-Making Profile (CDMP; Gati et al., 2010). 39-item self-report questionnaire based on Gati et al.'s multidimensional descriptive model of CDM. It is used to assess 12 dimensions (strategies) of CDM process-information gathering (comprehensive vs. minimal), information processing (analytic vs. holistic), locus of control (internal vs. external), effort invested (much vs. little), procrastination (high vs. low), speed of making final decision (fast vs. slow), consulting with others (frequent vs. rare), dependence on others (high vs. low), desire to please others (high vs. low), aspiration for ideal occupation (high vs. low), willingness to compromise (high vs. low), using intuition (much vs. little). Each dimension is assessed with three statements on a 7-point Likert-type scale $(1=$ do not agree at all; $7=$ highly agree). CDMP also includes a "warm-up" item and two validity items. Cronbach alpha for this study ranged $\alpha=.61-.87$.

Career Decision-Making Autonomy Scale (CDMAS; Guay, 2005). Self-report measure used to assess perceived autonomy via evaluating 4 forms of regulation dominating in people, when making decisions concerning activities encountered in various stages of CDM process. For each activity there are the same 4 items reflecting intrinsic motivation, identified regulation, introjected regulation,

\footnotetext{
${ }^{2}$ All questionnaires were back-translated into Slovak in cooperation with their original authors. As to their dimensionality and validity, Slovak and original English versions of the tools used in the present study correspond.
}

and external regulation. Items are rated on a 7-point Likert-type scale $(1=$ does not correspond at all; 7 = corresponds completely).

Academic Motivation Scale-College (AMS-C; Vallerand et al., 1992). 28- item English version of a French instrument Echelle de Motivation en Education (EME). It is based on SDT and used to measure one's level of self-determination in making career decisions concerning the choice of university study. It assesses three types of intrinsic motivation (intrinsic motivation to know, to accomplish things, and to experience stimulation), three types of extrinsic motivation (external, introjected, and identified regulation), and amotivation. There are seven subscales, each consisting of four items. Respondents rate reasons for their decision to go to college/university on a 7-point Likert scale $(1=$ does not correspond at all; $7=$ corresponds exactly). For purposes of the present study, we used only the Amotivation subscale. Cronbach alphas for this study ranged $\alpha=.75-.90$

Trait Meta-Mood Scale (TMMS; Salovey et al., 1995). 30-item, self-report measure designed to assess individuals' beliefs about attending to moods (Attention subscale, 13 items), clarity of their own experiences of mood (Clarity subscale, 11 items), and their efforts to repair mood states (Repair subscale, 6 items). Items are rated on a 5-point Likerttype scale $(1=$ strongly disagree, $5=$ strongly agree). Cronbach alphas for this study ranged $\alpha=.81-.88$.

\section{Procedure}

At the beginning, participants were met by a researcher who briefly acquainted them with the purposes of the study and made sure they became accustomed to the research 
context. Subsequently, the participants' task was to indicate their preference for each of the twelve CDMSs, their level of CDM autonomy (i.e., SD), and trait meta-mood experience (i.e., perceived EI) using the above described instruments (CDMP, CDMAS, AMS, TMMS).

\section{Data Analysis}

To test our hypotheses, we conducted Pearson correlation analyses followed by hierarchical regression analyses, which enabled us to investigate both, the potential of SD to be not only a correlate but also a predictor of using specific CDMSs, as well as to examine the role of perceived EI in predicting specific CDMSs, even after controlling for the SD effect.

\section{Results}

Relationships between all investigated variables are presented in Table 2. Correlations between CDMSs and autonomous versus nonautonomous types of motivation (levels of SD) were found to be low to moderate in their absolute values and almost half of them did not reach the level of statistical significance. Correlations between CDMSs and three aspects of perceived EI were also low to moderate. As to relationships between SD and perceived EI, we found small although significant correlations between two EI aspects - clarity of feelings and mood repair, and intrinsic motivation, both forms of nonautonomous regulation and amotivation.

The results of twelve hierarchical multiple regressions for twelve decision-making strategies are presented in Table 3. Five types of regulation (levels of SD) were entered simultaneously in the first step to control for pos- sible effects. In the second step, three subscales of perceived EI were added into the regression model simultaneously.

It was shown that in the first step, when five forms of regulation (levels of SD) were entered simultaneously, they jointly explained 2-34\% of variance in specific CDMSs. SD predicted the largest percentage of variance in aspiration for an ideal occupation, due to the large effect of intrinsic motivation (as well as external and introjected regulation). Willingness to compromise was least related to $\mathrm{SD}$. Intrinsic motivation was found to be the only or most important predictor for the effort invested and aspiration for ideal occupation. These adaptive strategies were more frequently used by intrinsic individuals. Identified regulation was an important predictor for adaptive strategies for comprehensive information gathering, analytic information processing, aspiration for ideal occupation and using intuition. Again, more identified individuals demonstrated the use of these strategies more frequently than those less identified. Introjected regulation accounted for significant though small amount of variance in consultation with others, dependence on others, desire to please others and aspiration for ideal occupation. Individuals with introjected regulation reported higher tendency to consult their career decisions with others, be dependent on others, and desire to please them, but also strive for ideal occupation. External regulation explained a significant proportion of variance in procrastination, desire to please others and aspiration for ideal occupation. The more externally regulated individuals, the higher the rates of procrastination and desire to please others accompanied with lower aspiration for ideal occupation. Amotivation was found to be an important 


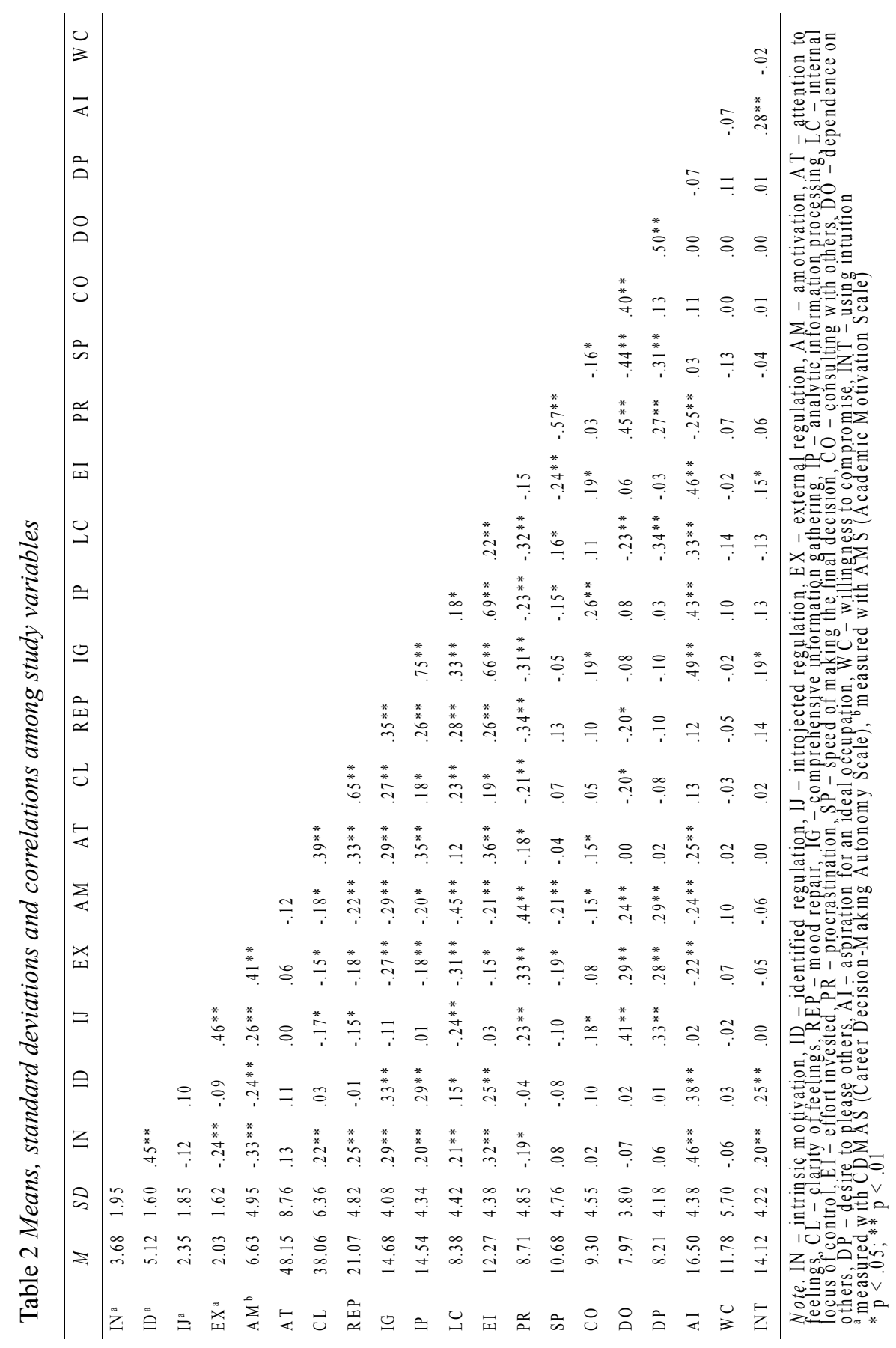




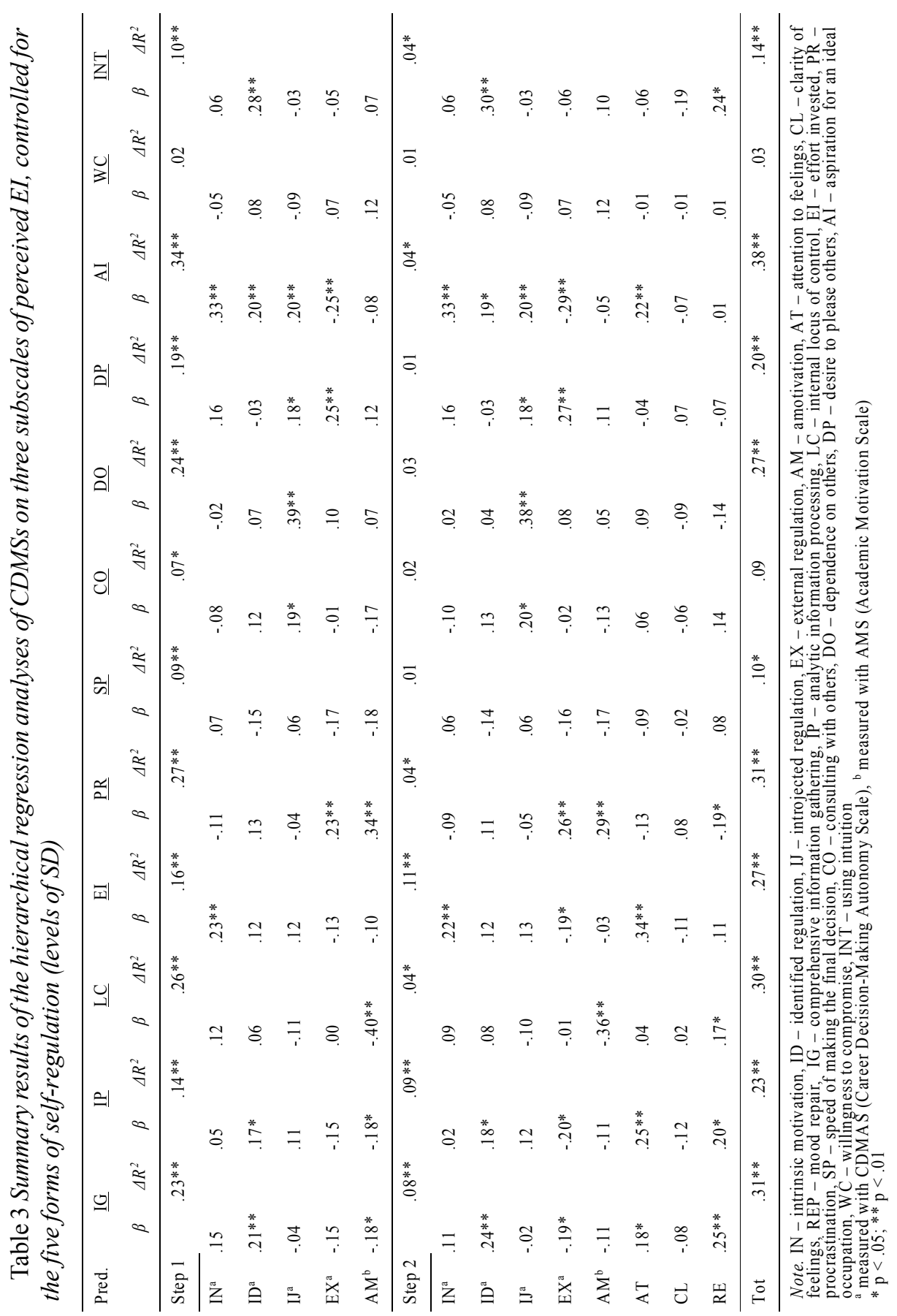


predictor for four CDMSs, specifically information gathering, information processing, locus of control and procrastination. It was shown that amotivated individuals gathered information only minimally, processed them holistically, had external locus of control and inclined to procrastinate.

In the second step, three subscales of perceived EI were added into regressions simultaneously and accounted for up to $11 \%$ of variance over and above SD. Both, attention to feelings and mood repair were important positive predictors of comprehensive information gathering and analytic information processing, which explained together an additional $8 \%$ of their variance. In addition, attention to feelings was an important positive predictor for invested effort and aspiration for ideal occupation, whereas mood repair was a positive predictor for internal locus of control, less procrastination and a great use of intuition. For other decisionmaking strategies, perceived EI did not contribute significantly to their preference, even when effects of SD were partialled out.

In general, our results are in accordance with expectations about the importance of $\mathrm{SD}$ and perceived EI for adaptive CDM.

\section{Discussion}

The present research was aimed at advancing knowledge about personality predictors of adaptive CDM, relying on Gati et al.'s assumption that the manner in which individuals make their career decisions may, to a certain degree, be conditioned by dispositional factors. Within this context, we tried to investigate whether SD and perceived EI may be seen as personality traits, explaining a significant portion of the variance in specific adaptive versus maladaptive CDMSs.

\section{Perceived Emotional Intelligence and Self-Determination}

The results of Pearson correlation analyses partly supported our predictions about the relationships between perceived EI and SD.

The findings that higher rates of two perceived EI dimensions, clarity of feelings and mood repair, were positively related to autonomous forms of regulation are consistent with most conceptions of EI, incorporating self-motivation as an essential component (e.g., Goleman, 1997). These findings might also be interpreted within the framework of Feeling-is-for-doing approach, which emphasizes the motivational function of emotions in human decision-making and behavior (Zeelenberg, Nelissen, Breugelmans, \& Pieters, 2008). Moreover, our findings are in line with the results of numerous studies providing evidence for positive relationships between perceived EI and career commitment (Brown, George-Curran, \& Smith, 2003), career engagement (Durán, Extremera, Rey, Fernández-Berrocal, \& Montalbán, 2006), or willingness to make career decisions (Di Fabio \& Palazzeschi, 2009).

Of course, we realize that the results yielded by correlation analyses do not enable us to reveal the direction and nature of causal relationships between perceived EI and SD. Here we refer to findings of two pilot studies conducted in 2005 by Green-Demers and in 2010 by Tadros and Green-Demers (as cited in Saad, 2011), implying that perceived EI is an antecedent of autonomous forms of regulation. However, with regard to relatively low absolute values of correlations between the two variables revealed in our research, it is quite possible that their level might be af- 
fected and their relationship mediated by some third variable. For instance, Spence, Oades, and Caputi (2003) hypothesize about self-awareness as a factor facilitating both, perceived EI and autonomous forms of regulation. Similarly, modern conceptions of personality integration theorize that mindful awareness is a precondition for autonomous motivation and a nondefensive approach to emotions, as a fundamental element of perceived EI (Weinstein et al., 2013). According to Qualter, Gardner, and Whiteley (2007), perceived EI might be promoted by one's perceptions of self-worth and self-esteem, which are also supposed to enhance SD (Deci \& Ryan, 2008). Although the nature of the relationships between perceived EI and SD remains an open question, detailed analysis of the presented results reveals several findings that should not be omitted from discussion.

One may see as contradictory that Attention to feelings was not significantly related to any form of autonomous or nonautonomous regulation. This may be interpreted by both, nature of their relationships and multidimensionality of TMMS Attention subscale.

As to the nature of the relationships between attention to feelings and autonomy of CDM motivation, it is quite possible that it is not linear but follows a rather curvilinear, inverted U-shaped curve. This assumption is supported by numerous research findings, indicating that only moderate level of attention to feelings is positively associated with various well-being indicators, including autonomous motivation (Fernández-Berrocal \& Extremera, 2008; Salovey et al., 2002).

As argued above, nonsignificant relationships between investigated variables may also reflect multidimensionality of TMMS
Attention subscale. As Salovey et al. (1995) report, Attention subscale assesses not only one's perceived ability to monitor one's feelings but it also expresses one's attitude to experienced emotions. It may be the case that persons high in intrinsic motivation and/or identified regulation appreciate emotional experiences, regardless of the level of their awareness. On the other hand, nonautonomously regulated individuals are expected to deflate the role of emotions, no matter whether they currently notice them or not (Deci \& Ryan, 1985, 2008).

\section{Self-Determination and Career Decision- Making Strategies}

Our findings indicate that SD, which in previous research by Guay et al. (2005) was found to be an important predictor of adaptive CDM in terms of explaining career undecidedness, also plays a crucial role in predicting preference for specific adaptive CDMSs. Autonomous and nonautnomous forms of regulation jointly accounted for a significant portion of variance in all but one of the twelve investigated CDMSs (except willingness to compromise).

As can be seen in Table 3, our hypotheses about autonomous forms of regulation, as significant predictors of adaptive CDMSs, were partly supported by our results. Specifically, it was shown that intrinsically motivated participants invested much effort in the CDM process and strived intensively for ideal occupation. Moreover, participants reporting higher levels of identified regulation demonstrated a preference for comprehensive information gathering, analytic information processing as well as using intuition when making career choices. This indicates that the encouragement of both, intrinsic 
motivation and identified regulation, based on facilitating nondefensiveness against subjective experiences and core aspects of self, may increase an individuals' effort invested in the CDM process, their aspiration for ideal occupation and, what more, their ability to use intuitive as well as analytic decision-making processes adaptively and without the need to prefer one to the other.

The findings that autonomous forms of regulation were not important predictors of some maladaptive CDMSs (i.e., external locus of control, slow speed of making a final decision, procrastination, desire to please others and dependence on others) may be interpreted as indicative of variability with which these ways of making career decisions are adopted by individuals high in intrinsic motivation and/or identified regulation. In other words, it is possible that autonomously regulated individuals decide differently, in some aspects, which does not have to mean that they decide more or less adaptively. For example, when some autonomously regulated individuals spend more time on making a final decision, it may be associated with the effort invested in the CDM process, including comprehensive information gathering and analytic information processing. Similarly, higher dependence on others or desire to please them may in some autonomously regulated decision-makers reflect the continuous need for help and support from important others, which is only natural in young adulthood. On the other hand, opposite tendencies may be explained as a consequence of striving to become increasingly free in making their career decisions.

As regards nonautonomous forms of regulation, we discovered that the more externally regulated individuals, the higher the rates of procrastination and desire to please others, accompanied by lower aspiration for ideal occupation. Similarly, amotivated individuals were shown to gather information only minimally and process them holistically, to have external locus of control and incline to procrastinate. This may be interpreted as a sign of their defensive approach to the CDM process, which directly results, according to SDT, from the existing incongruence between core aspects of self and career goals.

It is important to emphasize that findings about CDMSs in participants reporting high introjected regulation were mixed and less convincing than those concerning externally regulated and amotivated individuals. Contrary to our expectations, introjected regulation predicted not only maladaptive tendencies for dependence on others and desire to please them, but also consulting one's career choices with others and preference for adaptive aspiration for ideal occupation. Since neither rare nor frequent consultation with others was proved to be more or less adaptive in previous research (Gadassi et al., 2012, 2013), the conclusion whether and when introjected individuals consult with others in adaptive or maladaptive ways remains an open question. As to high aspiration for ideal occupation, it is possible that there are some, yet uninvestigated personality or social factors affecting preference for this strategy in introjected individuals. All in all, future research is needed to clarify adaptiveness of decision-making processes running in individuals regulated mostly by introjection.

On the other hand, findings concerning high levels of dependence on others and/or desire to please others in both, introjected and external regulation, provide ample support for two basic SDT propositions that (a) individuals high in introjected regulation 
are motivated to decide and behave in line with internalized prescriptions and proscriptions of important others, which, if violated, cause them to experience feelings of guilt, shame, and anxiety, whereby making them dependent on important others' approval and positive regard; (b) externally regulated individuals are motivated to decide and behave in ways that enable them to gain rewards or avoid penalties, which is again fully consistent with their dependence on others and desire to please them.

Perceived Emotional Intelligence and Career Decision-Making Strategies

The results yielded by hierarchical regression analyses indicate that three perceived EI dimensions jointly explain the preference for some adaptive CDMSs as well as the tendency to use fewer of the maladaptive ones, even after controlling for the SD effects.

Our findings that perceived EI is positively related to preference for some adaptive CDMSs provide support for most conceptions of perceived EI, emphasizing beneficial effects of one's subjective beliefs about their abilities to become aware of, differentiate, regulate and utilize emotions as sources of information when making decisions (Gohm \& Clore, 2002; Salovey et al., 1995). This point is reinforced by the finding that people high in perceived EI dimensions, representing basic intrapersonal components of perceived EI, show less of a tendency to adopt some maladaptive avoidant strategies of external locus of control and procrastination (Di Fabio, 2012; Sarmány-Schuller, 1999). These findings led us to conclude that perceived EI might be regarded not only as one of the personality predictors of adaptive CDM but also as an important dispositional factor protecting one against developing maladaptive patterns of CDM.

Although Gati et al. (2010) classified the strategies of dependence on others, desire to please others and low speed of making a final decision as maladaptive, our findings that these strategies are not significantly related to and predicted by perceived EI are not to be interpreted as evidence questioning the positive effects of its three dimensions on adaptive CDM. Low speed of making a final decision might indicate not only one's undecidedness but also the effort and time invested in information gathering and processing (Gati et al., 2010). Our finding concerning the nonsignificant relationships between perceived EI and the use of the strategies dependence on others and desire to please others may imply that there are some interpersonal factors affecting the preference for these strategies. Because neither the conception of meta-mood experience nor the instrument used to measure it (TMMS) catch the interpersonal aspect of perceived EI (Salovey et al., 1995), our research results did not enable us to reveal these effects. Similar interpretation might be applied to nonsignificant findings concerning the strategy consultation with others (Gati et al., 2010).

The assumption about other, here uninvestigated, inter- and intrapersonal factors affecting the CDM process, is also implied by our findings about nonsignificant relationships between and preference for the strategy willingness to compromise as well as findings concerning significant relationships between perceived EI and adoption of strategies of aspiration for an ideal occupation and using intuition.

Findings regarding the strategy willingness to compromise may be interpreted as 
indicative of interpersonal differences in maximizing versus satisficing (Schwartz et al., 2002). It might be expected that regardless of perceived EI, both maximizers and satisficers would pursue different CDM goals. They might process emotional information and regulate decision-related emotions in different ways, which might lead them to adopt different decision-making strategies (Bettman, Luce, \& Payne, 1998). As maximizers strive for maximizing accuracy or utility of their decisions, they might not prefer to compromise and tend to use different ways of making career decisions (e.g., strive for an ideal occupation). In contrast, satisficers attempting to minimize the cognitive effort when making decisions and thus accepting suboptimal choices, might prefer this strategy.

We consider this explanation sensible, in the light of the findings that attention to feelings predicts aspiration for ideal occupation. It may be the case that both maximizers and satisficers demonstrate higher scores on TMMS attention subscale because of their tendency to follow the hedonic value of decision outcomes (Salovey et al., 1995, 2002). As a consequence of their sensitivity to emotional information valence, they may be attracted by the ideal occupation having the highest hedonic value. However, after perceiving and differentiating negative anticipated emotions (e.g., regret), induced when realizing the risk of not achieving the preferred decision-making goals, it is highly probable that only maximizers would keep using the strategy of aspiration for ideal occupation (Bettman et al., 1998).

There are several plausible explanations for the seemingly contradictory finding as well, that mood repair accounts for a significant portion of variance in the preference for both, intuitive and rational CDMSs (i.e., using intuition, comprehensive information gathering and analytic information processing). Although there may be some individual differences in adopting intuitive versus rational (analytical) decision styles (SarmánySchuller \& Kuračka, 2012), it is possible that individuals being able to effectively regulate their negative emotions can also adaptively manage the extent to which they use intuitive versus rational processes when making career decisions. This indicates that in emotionally intelligent persons, their ability to use intuitive versus rational decision styles may represent a flexible capacity rather than a fixed personality trait. This assumption is also supported by modern theories, conceptualizing intuitive thinking as an unconscious process driven by previous experience. Hence, it might be expected that decision-makers with various amounts of previous experience in CDM would also differ in their preference for intuitive and rational CDMSs. Similarly, according to the dual-process approach, intuitive processes are triggered and adaptively utilized particularly in complex decision-making situations, which are typical of lack of time or information needed to make a final decision. From this perspective, decision-makers who are placed in a complex situation when making career decisions, might tend to use intuition to a greater extent than those not subjected to time pressure or poor informational sources (Sarmány-Schuller, 2010). Taken together, this finding may help reconcile theorists and researchers arguing for and against adaptiveness of rational versus intuitive decision styles or strategies, as well as outline the opportunity for future research.

By integrating these results, we might conclude that individuals reporting higher rates 
of perceived EI are not only more sensitive and open to their feelings, but they are also letting emotional information be a guide of their cognitive processes concerning comprehensive information gathering and analytical information processing. In addition to being cognitively "skillful", emotionally intelligent decision-makers are intuitive, believe in their abilities to control outcomes of their decisions (i.e., have internal locus of control) and demonstrate lower tendencies to procrastinate when making career decisions.

\section{Limitations and Future Directions}

The present research has four main limitations.

First, the measurement instruments used to assess CDMSs, SD and perceived EI were self-reported. Therefore, our results might have been affected by the participants' tendency for social desirability or other drawbacks associated with this questionnaire methodology. This, we hope, will stimulate future research conducted via experiments or observations.

Second, the potential of SD and perceived EI as important predictors of using specific CDMSs, were assessed via regression analyses, which do not enable us to determine causality of relationships between investigated variables. Experimental as well as longitudinal studies are needed to further test assumptions about SD and perceived EI, as personality factors playing a crucial role in preference for adaptive CDMSs.

Third, since we decided to include only university female students in our sample, our findings are limited to young adult women. In order to identify possible gender differences, future studies should be replicated on male samples (in our research program we have already been working on filling this gap in current knowledge).

Finally, our findings, especially those concerning the participants' preferences for each CDMS, may be specific to Slovak conditions and to the situation on Slovak labor market. Although previous studies, comparing culturally different samples (Israeli and North American), showed that young adults' CDM profiles are quite similar (Gati et al., 2010), we cannot be sure that these findings also hold true for Slovak young adults before conducting similar intercultural comparison within a Slovak setting. However, we believe that our findings about the preference for specific CDMSs may be similar in other Central-European countries. Future studies are needed to investigate whether the preference for particular CDMSs is different in Western and Eastern cultures. It is possible that in different cultures some strategies may reflect typical societal norms, which are not characteristic for other cultural settings and thereby may be present in CDM profile of individuals living in different cultures to various extent.

\section{Implications}

The contribution of the present research may be seen in both, theoretical and empirical area.

In the field of theory, we attempted to converge and integrate knowledge about the role of perceived (or trait) EI and other personality variables (including SD) in adaptive decision making with alternative, other-thanrational, conceptions of using adaptive CDMSs. Our investigation provided empirical support for several theoretical conceptions, for instance, normative models of CDM 
adaptiveness (Gati \& Tal, 2008; Phillips, 1997), with Gati et al.'s (2010) career decision-making profile being the standard, modern conceptions of personality integration (Weinstein et al., 2013), SDT (Deci \& Ryan, 1985, 2008), conceptions of trait/perceived EI (Petrides \& Furnham, 2000, 2001; Salovey et al., 1995, 2002), Feeling-is-for-doing approach (Zeelenberg et al., 2008) or Affect-asinformation theory (Gohm \& Clore, 2002). What is more, we offered a rather novel viewpoint on the nature of personality dispositions, predicting preference for adaptive CDMSs, which is based on modern conceptions of personality integration (Weinstein et al., 2013).

In the field of practice, our results could be utilized, at least informatively, in career counselling. The focus on SD and perceived EI, as potential personality factors of adaptive CDM, is especially important considering the fact that these traits may be, despite their dispositional nature, facilitated when the individual's important others, including career counsellors, use the autonomy-supportive interpersonal style (Deci \& Ryan, 2008) and are supportive of the individuals' perceptions of self-worth and self-esteem (Qualter, Gardner, \& Whiteley, 2007). As we have discovered, preference for adaptive CDMSs is closely connected to the level of SD as well as to two perceived EI dimensions, attention to one's feelings and mood repair. This implies that examination of students' SD level, and self-perceptions about their emotional-cognitive competencies along with encouragement of both, students' SD and perceived EI, might facilitate their adaptive CDM. In the very end, we recommend that counselling-interventions should be focused on young adults for whom the formation, maintenance, improvement and adaptive use of CDMSs represent a crucial developmental task.

Received June 18, 2014

\section{References}

Avsec, A. (2012). Do emotionally intelligent individuals use more adaptive decision-making styles? Studia Psychologica, 54(3), 209-220. Retrieved from http://web.a.ebscohost.com/ehost/pdfviewer /pdfviewer?sid=584c6d17-32ae-467f-82f916 f8c98da9b4\%40sessionmgr4001\&vid $=4 \&$ hid $=4207$

Bettman, J. R., Luce, M. F., \& Payne, J. W. (1998). Constructive consumer choice processes. Journal of Consumer Research, 25(3), 187-217. doi:10.1086/209535

Brown, C., George-Curran, R., \& Smith, M. L. (2003). The role of emotional intelligence in the career commitment and decision-making process. Journal of Career Assessment, 11(4), 379392. doi:10.1177/1069072703255834

Deci, E. L., \& Ryan, R. M. (1985). Intrinsic motivation and self-determination in human behavior. New York: Plenum Press. Retrieved from http://books.google.sk/books?id=p96 WmnER4QC\&printsec $=$ frontcover $\&$ hl $=$ sk\&source $=$ gbs_ge_summary_r\&cad $=0 \# \mathrm{v}=$ onepage $\& \mathrm{q} \& \mathrm{f}=$ false

Deci, E. L., \& Ryan, R. M. (2008). Self-determination theory: A macrotheory of human motivation, development, and health. Canadian Psychology, 49(3), 182-185. doi:10.1037/a0012801

DeHaan, C. R., Weinstein, N., \& Deci, E. L. (2013, June). Autonomous life decisions and regret. Poster session presented at the 5th International Conference on Self-Determination Theory, Rochester, NY. Retrieved from http://static1. squarespace.com/static/ 53 fa 8369 e 4 b0 af $75 \mathrm{~d} 681$ be $16 / \mathrm{t} / 53 \mathrm{fb} 5 \mathrm{~d} 2 \mathrm{de} 4 \mathrm{~b} 08 \mathrm{bf} 8 \mathrm{~d} 1 \mathrm{~d} 0 \mathrm{f} 573 /$ 1408982317354/SDT-2013-Poster.pdf

Di Fabio, A., \& Blustein, D. L. (2010). Emotional intelligence and decisional conflict styles: Some empirical evidence among Italian high school students. Journal of Career Assessment, 18(1), 71-81. doi:10.1177/1069072709350904

Di Fabio, A., \& Kenny, M. E. (2012). The contribution of emotional intelligence to decisional styles among Italian high school students. Journal of Career Assessment, 20, 404-414. doi: $10.1177 / 1069072712448893$ 
Di Fabio, A., \& Palazzeschi, L. (2009). Emotional intelligence, personality traits and career decision difficulties. International Journal for Educational and Vocational Guidance, 9(2), 135146. doi: $10.1007 / \mathrm{s} 10775-009-9162-3$

Di Fabio, A., \& Saklofske, D. H. (2014). Comparing ability and self-report trait emotional intelligence, fluid intelligence, and personality traits in career decision. Personality and Individual Differences, 64, 174-178. doi:10.1016/j.paid.2014. 02.024

Di Fabio, A., Palazzeschi, L., \& Bar-On, R. (2012). The role of personality traits, core self-evaluation and emotional intelligence in career decision-making difficulties. Journal of Employment Counseling, 49, 118-129. doi:10.1002/j.21611920.2012.00012.x

Di Fabio, A., Palazzeschi, L., Asulin-Peretz, L., \& Gati, I. (2013). Career indecision versus indecisiveness: Associations with personality traits and emotional intelligence. Journal of Career Assessment, 21, 42-56. doi:10.1177/10690727124 54698

Durán, A., Extremera, N., Rey, L., FernándezBerrocal, P., \& Montalbán, F. M. (2006). Predicting academic burnout and engagement in educational settings: Assessing the incremental validity of perceived emotional intelligence beyond perceived stress and general self-efficacy. Psicothema, 18(Suplemento), 158-164. Retrieved from http:/ /www.psicothema.com/pdf/3292.pdf

Fernández-Berrocal, P., \& Extremera, N. (2008). A review of trait meta-mood research. In A. M. Columbus (Ed.), Advances in psychology research. Vol 55, (pp. 17-45). Hauppauge, NY, US: Nova Science Publishers. Retrieved from http:// www.google.sk/books?hl=sk \&lr=\&id=iVG $4 \mathrm{cKfGp} 2 \mathrm{MC} \&$ oi $=$ fnd \&pg $=$ PA $17 \& \mathrm{dq}=\% 22 \mathrm{~A}+$ review + of + trait + meta-mood + research $\% 22 \&$ ots $=$ YAODPbbg2 O \&sig=T fvAT v9XTZyy 82

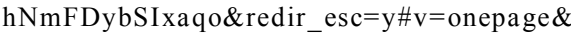
$\mathrm{q}=\% 22 \mathrm{~A} \% 20$ review $\% 20$ of $\% 20$ trait $\% 20$ meta$\operatorname{mood} \% 20$ research $\% 22 \& \mathrm{f}=$ false

Gadassi, R., Gati, I., \& Dayan, A. (2012). The adaptibility of career decision-making profiles. Journal of Counseling Psychology, 59(4), 612622. doi: 10.1037/a0029155

Gadassi, R., Gati, I., \& Wagman-Rolnick, H. (2013). The adaptibility of career decision-making profiles: Associations with self-efficacy, emotional difficulties, and decision status. Journal of $\mathrm{Ca}$ reer Development, 40(6), 490-507. doi:10.1177/ 0894845312470027
Gati, I., Landman, S., Davidovitch, S., Asulin-Peretz, L., \& Gadassi, R. (2010). From career decisionmaking styles to career decision-making profiles: A multidimensional approach. Journal of Vocational Behavior, 76(2), 277-291. doi:10.1016/ j.jvb.2009.11.001

Gohm, C. L., \& Clore, G. L. (2002). Affect as information: An individual differences approach. In L. Feldman Barrett \& P. Salovey (Eds.), The wisdom in feeling: Psychological processes in emotional intelligence (pp. 89-113). New York: Guilford Press. Retrieved from http://www. google.sk/url? sa $=t \& r c t=j \& q=\&$ esrc $=s \&$ source $=$ web \& cd $=3 \&$ ved $=0$ CCWQFjAC \& url=http $\% 3 \mathrm{~A} \% 2 \mathrm{~F} \% 2 \mathrm{Fwww}$.ibrarian.net $\% 2 \mathrm{Fnavon} \% 2 \mathrm{Fpaper} \% 2 \mathrm{FAffect}$ as Information $1 . \mathrm{pdf} \% 3 \mathrm{~F}$ paperid\%3D17028857\& $\mathrm{e} i=\mathrm{n} 7 \mathrm{~L} A \bar{V} \mathrm{~L} z z \mathrm{C} 4 \mathrm{GiUNqG}$ geA M \&usg= AFQjCNEGrZJCbv1P1dOx M8nExjt9a 1Pig\&sig2=bOfNAfQPoEWflvv7DbxaRA

Goleman, D. (1997). Emoční inteligence. Praha: Columbus.

Guay, F. (2005). Motivations underlying career decision-making activities: The Career DecisionMaking Autonomy Scale (CDMAS). Journal of Career Assessment, 13(1), 77-97. doi:10.1177/ 1069072704270297

Guay, F., Senécal, C., Gauthier, L., \& Fernet, C. (2003). Predicting career indecision: A self-determination theory perspective. Journal of Counseling Psychology, 50(2), 165-177. doi:10.1037/ 0022-0167.50.2.165

Jurišová, E., \& Sarmány-Schuller, I. (2013). Structure of basal psychical self-regulation and personality integration in relation to coping strategies in decision-making in paramedics. Studia Psychologica, 55(1), 3-17. Retrieved from http:/ /web.a.ebscohost.com/ehost/pdfviewer/ pdfviewer? sid=584c6d17-32ae-467f-82f916 f 8 c 98 da 9 b $4 \% 40$ sessionmgr $4001 \&$ vid $=8$ \& hid $=4207$

Laborde, S., Dosseville, F., \& Scelles, N. (2010). Trait emotional intelligence and preference for intuition and deliberation: Respective influence on academic performance. Personality and Individual Differences, 49, 784-788. doi:10.1016/ j.paid.2010.06.031

Látalová, V., \& Pilárik, L. (2013). Autonómia motivácie kariérnej vol'by a spokojnost' $\mathrm{s}$ rozhodovaním. In I. Sarmány-Schuller (Ed.), Otázniky rozhodovania: Teória, empiria, život. Zborník príspevkov z konferencie 31. Psychologické dni (pp. 180-187). Bratislava: Stimul. 
Látalová, V., \& Pilárik, L. (in press). Adaptívnost' stratégií kariérového rozhodovania vo vzt'ahu k prežívaniu spokojnosti a l'útosti $v$ rozhodovacom procese. In: Zborník príspevkov z konfrencie Rozhodovanie v kontexte kognície, osobnosti a emócií IV, Bratislava (2014, June).

Mayer, J. D., \& Salovey, P. (1997). What is emotional intelligence? In P. Salovey \& D. Sluyter (Eds.), Emotional development and emotional intelligence: Educational implications (pp. 331), New York: Basic Books. Retrieved from http:/ /www.unh.edu/emotional intelligence/ EI\%20 Assets/Reprints... EI\%20 Proper/ EI1997MSWhatIsEI.pdf

Petrides, K. V., \& Furnham, A. (2000). On the dimensional structure of emotional intelligence. Personality and Individual Differences, 29(2), 313-320. doi:10.1016/S0191-8869(99)00195-6

Petrides, K. V., \& Furnham, A. (2001). Trait emotional intelligence: Psychometric investigation with reference to established trait taxonomies. European Journal of Personality, 15, 425-448. doi: $10.1002 /$ per.416

Phillips, S. D. (1997). Toward an expanded definition of adaptive decision making. The Career Development Quarterly, 45(3), 275-287. doi: 10.1002/j.2161-0045.1997.tb00471.x

Pilárik, L', \& Sarmány-Schuller, I. (2009). Emotional intelligence and decision-making of female students of social work in the Iowa Gambling Task. Studia Psychologica, 51(4), 319-328.

Qualter, P., Gardner, K. J., \& Whiteley, H. E. (2007). Emotional intelligence: Review of research and educational implications. Pastoral Care in Education, 25(1), 11-20. doi:10.1111/j.14680122.2007.00395.x

Saad, K. (2011). Emotionally Smart Makes You More Motivated (Doctoral dissertation, University of Ottawa). Retrieved from http:// www.ruor.uottawa.ca/bitstream/10393/20107/1/ Saad_Karene_2011_thesis.pdf

Salovey, P., \& Mayer, J. D. (1990). Emotional intelligence. Imagination, Cognition and Personality, 9, 185-211. doi: 10.2190/DUGG-P24E$52 \mathrm{WK}-6 \mathrm{CDG}$

Salovey, P., Mayer, J. D., Goldman, S. L., Turvey, C., \& Palfai, T. P. (1995). Emotional attention, clarity, and repair: Exploring emotional intelligence using the Trait Meta-Mood Scale. In J. W. Pennebaker (Ed.), Emotion, disclosure and health (pp. 125-154). Washington, D.C.: American Psychological Association. Retrieved from http:// www.unh.edu/emotional_intelligence/
EI\%20Assets/Reprints...Mood\%20Meas\% 20 and\%20Mood\%2 0Cong/CA1995 Salovey Mayer.pdf

Salovey, P., Stroud, L. R., Woolery, A., \& Epel, E. S. (2002). Perceived emotional intelligence, stress reactivity, and symptom reports: Further explorations using the trait meta-mood scale. Psychology and Health, 17(5), 611-627. doi:10.1080/ 08870440290025812

Sarmány-Schuller, I. (1999). Procrastination, need for cognition and sensation seeking. Studia Psychologica, 41(1), 73-85.

Sarmány-Schuller, I. (2010). Decision making under time pressure in regard to preferred cognitive style (analytical-intuitive) and study orientation. Studia Psychologica, 52(4), 285-290.

Sarmány-Schuller, I., \& Kuračka, P. (2012). Dimension of the cognitive style "analytical-intuitive" and the successful problem solving in the "IGT" experimental situation. Studia Psychologica, 54(2), 95-109. Retrieved from http:// web.a.ebscohost.com/ehost/pdfviewer/ pdfviewer?vid $=12 \& \operatorname{sid}=584 \mathrm{c} 6 \mathrm{~d} 17-32 \mathrm{ae}-467 \mathrm{f}$ $82 \mathrm{f} 9-16 \mathrm{f} 8 \mathrm{c} 98 \mathrm{da} 9 \mathrm{~b} 4 \% 40$ sessionmgr4001\& hid $=4207$

Schwartz, B., Ward, A., Monterosso, J., Lyubomirsky, S., White, K., \& Lehman, D. R. (2002). Maximizing versus satisficing: Happiness is a matter of choice. Journal of Personality and Social Psychology, 83(5), 1178-1197. doi: 10.1037//0022-3514.83.5.1178

Schwarz, N. (2012). Feelings-as-information theory. In P. Van Lange, A. Kruglanski, \& E. T. Higgins, Handbook of Theories of Social Psychology (pp. 289-308). London, UK: SAGE. Retrieved from http://people.ict.usc.edu/ gratch/CSCI534/ schwarz_feelings-as-information_7jan10.pdf

Seo, M. G., \& Barrett, L. F. (2007). Being emotional during decision making - Good or bad? An empirical investigation. Academy of Management Journal, 50(4), 923-940. Retrieved from http://www.ncbi.nlm.nih.gov/pmc/articles/ PMC2361392/pdf/nihms37842.pdf

Sheldon, K. M., \& Kasser, T. (1995). Coherence and congruence: Two aspects of personality integration. Personality and Social Psychology Bulletin, 68, 531-543. doi:10.1037//00223514.68.3.531

Spence, G., Oades, L. G., \& Caputi, P. (2004). Trait emotional intelligence and goal self-integration: Important predictors of emotional well-being? Personality and Individual Differences, 37(3), 449-461. doi:10.1016/j.paid.2003.09.001 
Vallerand, R. J., Pelletier, L. G., Blais, M. R., Briere, N. M., Senecal, C., \& Vallieres, E. F. (1992). The Academic Motivation Scale: A measure of intrinsic, extrinsic, and amotivation in education. Educational and psychological measurement, 52(4), 1003-1017. doi:10.1177/00131644920520 04025

Weinstein, N., Przybylski, A. K., \& Ryan, R. M. (2013). The integrative process new research and future directions. Current Directions in Psychological Science, 22(1), 69-74. doi:10.1177/ 0963721412468001

Zeelenberg, M., Nelissen, R. M. A., Breugelmans, S. M., \& Pieters, R. (2008). On emotion specificity in decision making: Why feeling is for doing. Judgment and Decision-Making, 3(1), 18-27. Retrieved from http://journal.sjdm.org/ bb2.pdf

\title{
PREDIKCIA STRATÉGII KARIÉROVÉHO ROZHODOVANIA U ŽIEN: ÚLOHA SEBADETERMINÁCIE A VNÍMANEJ EMOČNEJ INTELIGENCIE
}

\author{
V. L á t a 1 ová, L. P i 1 á r i k
}

Súhrn: Cielom výskumu bolo overit' úlohu sebadeterminácie (SD) a vnímanej emočnej inteligencie (EI) v uplatňovaní adaptívnych stratégií kariérového rozhodovania, a tým prispiet' k rozšíreniu poznania ohl'adne osobnostných faktorov zohrávajúcich kl'účovú rolu v uskutočňovaní adaptívnych rozhodnutí, a to najmä v oblasti kariérových volieb. Výskumné zámery sme realizovali na vzorke 173 VŠ študentiek 1. ročníka vo veku 19-25 rokov s využitím dotazníkov Career Decision-Making Profile (CDMP; Gati et al., 2010), Career Decision-Making Autonomy Scale (CDMAS; Guay, 2005), Academic Motivation Scale-College (AMS-C; Vallerand et al., 1992) a Trait Meta-Mood Scale (TMMS; Salovey et al., 1995). Výsledky podporili predpoklad o dôležitosti SD ako aj vnímanej EI pre adaptívne kariérne rozhodovania; zatial' čo SD vysvetlovala 2-34\% variancie v uplatňovaní špecifických stratégií kariérového rozhodovania, vnímaná EI vysvetl'ovala po kontrolovaní účinkov SD dodatočných takmer $11 \%$ variancie ich uplatňovania. Vyššia SD a vnímaná EI sa spájali s častejším používaním adaptívnych, a naopak, menej častým uplatňovaním neadaptívnych stratégií kariérového rozhodovania. Zistenia možno využit'v kariérovom poradenstve. 